\title{
APLIKASI PENGGUNAAN EKSTRAK NANAS DAN RAGI ROTI SEBAGAI BIOKATALISATOR PEMBUATAN VCO (Virgin CoconutOil) SERTA PEMURNIANNYA DENGAN MENGGUNAKAN ZEOLIT ALAM BENGKULU DAN ABU SEKAM PADI
}

\author{
Application Of Pineapple Extract And Bread Yeast As A Biocatalizer In The \\ Making Of Vco (Virgin Coconut Oil) And Its Purification By Using Bengkulu \\ SNatural Zeolite And Rice Husk Ash
}

\author{
Dyah Fitriani*, Eni Widiyati, Deni Agus Triawan \\ Program Studi Kimia, Fakultas MIPA Universitas Bengkulu, Bengkulu \\ email: dyah.fitriani@unib.ac.id
}

\begin{abstract}
Abstrak. Ekstrak nanas dan ragi roti diketahui sama-sama mengandung enzim protease. Enzim protease dapat berfungsi sebagai biokatalisator untuk mempercepat proses hidrolisis protein pada emulsi santan sehingga minyak VCO dapat terambil dari santan. Penelitian ini bertujuan untuk membuatminyak Virgin Coconut Oil (VCO) dengan memanfaatkan ekstrak nanas dan ragi roti kemudian VCO yang diperoleh dimurnikan dengan menggunakan adsorben zeolit alam yang berasal dari Propinsi Bengkulu dan juga abu sekam padi. Rendemen VCO terbesar diperoleh pada waktu fermentasi selama 24 jam yaitu sebesar $43,24 \%$ dengan nilai kadar air sebesar $0,79 \%$; asam lemak bebas $0,633 \%$; bilangan peroksida $2,23 \mathrm{meq} / \mathrm{kg}$; warna VCO kuning pucat danberaroma khas minyak kelapa. Setelah VCO dimurnikan dengan adsorben zeolit alam yang dan abu sekam padi terjadi penurunan nilai kadar air, asam lemak bebas dan bilangan peroksida serta warna VCO menjadi bening dan kuning pucat. Setelah dilakukan pemurnian, maka kualitas VCO yang diperoleh telah memenuhi SNI 01-2901-2008.
\end{abstract}

Kata kunci: ekstrak nanas, VCO, zeolit alam, abu sekam padi

Abstract. Pineapple extract and bread yeast both showed activity as a protease enzyme. This enzyme functionates as biocatalizer to accelerate the protein hydrolysis process on coconut cream emulsion so that VCO oil can be obtained. This study aimed to make virgin coconut oil (VCO) with a combination of fermentation and enzymatic methods and then VCO was purified with natural zeolite from Bengkulu province and rice husk ash adsorbent. The highest VCO yield was obtained at the incubation time for 24 hours, namely $43.24 \%$ with a water content value of $0.79 \%$; free fatty acids of $0.633 \%$; peroxide number of 2.23 meq / kg; VCO color was pale yellow and had a distinctive aroma of coconut oil. After the VCO was purified with natural zeolite and rice husk ash adsorbent, there was a decrease in the value of water content, free fatty acids and peroxide values. The color of VCO became colorless and yellowish. After the VCO was purified, the quality of the VCO obtained had met requirement set by SNI 01-2901-2008 standards.

Keywords: pineaple extract, VCO, natural zeolite, rice husk ash 


\section{PENDAHULUAN}

Virgin Coconut Oil (VCO) merupakan salah satu produk olahan dari daging buah kelapa yang sudah tua. VCO diproduksi secara mekanis dan alami, tanpa ataupun menggunakan panas sehingga tidak menyebabkan perubahan kandungan pada minyak. VCO mengandung asam laurat yang tinggi sekitar 46,36- 48,42\% (Mansor, Che Man, Suhaimi, Abdul Afiq, \& Ku Nurul, 2013). Asam laurat merupakan medium chain fatty acid (MCFA) yang memiliki nilai fungsional dan nutrisi yang sangat baik bagi tubuh(Diyah, Purwanto, Susanti, \& Dewi, 2010). Pembuatan VCO secara tradisional yang telah banyak dilakukan oleh masyarakat di pedesaan, pada uumnya akan menghasilkan kualitas VCO yang kurang baik dan rendemen yang rendah (Palilingan \& Pungus, 2018).

Salah satu metode yang dipakai dalam memproduksi VCO yaitu metode enzimatis dengan menggunakan enzim bromelin. Enzim bromelin merupakan enzim yang banyak terdapat pada tanaman nanas, baik di batang, daun, kulit, daging buah ataupun bonggol. Enzim ini termasuk dalam enzim protease yang dapat mengkatalisis reaksi pemecahan protein dengan menghidrolisis ikatan peptidanya menjadi molekulmolekul yang lebih sederhana yaitu asam amino. Pemanfaatan enzim bromelin dari bonggol nanas dalam proses pembuatan VCO telah dilakukan oleh Ishak, Aji, \& Israwati (2015), dalam penelitiannya semakin banyak ekstrak bonggol nanas yang ditambahkan maka semakin besar rendemen VCO yang dihasilkan. Demikian juga Fuad (2012) pernah membuat VCO dengan menggunakan enzim bromelin yang berasal dari nanas.

Selain metode enzimatis, VCO juga dapat diperoleh dengan metode fermentasi menggunakan mikroorganisme. Mikroorganisme yang sering dipakai antara lain Sacharomyces cereviceae. Mikroorganisme ini dapat ditemukan pada ragi roti. Aditya, Rusmarilin, \& Limbong (2014) telah melakukan penelitian mengenai pembuatan VCO menggunakan ragi roti, dari hasil penelitiannya menunjukkan rendemen VCO yang dihasilkan semakin meningkat dengan semakin banyaknya konsentrasi ragi roti yang ditambahkan. Pemanfaatan ragi roti yang mengandung Saccaharomyces cereviceae yang merupakan enzim proteolitik dapat menghidrolisis ikatan peptida pada emulsi santan (Simangunsong, Febrina, \& Masyitah, 2016). Penelitian yang dilakukan oleh Mujdalipah (2016) mengenai penggunaan tiga jenis ragi dalam proses pembuatan VCO yaitu ragi roti, ragi tape dan ragi tempe, dimana ketiga jenis ragi ini sama-sama mengandung enzim protease. Rendemen VCO terbesar diperoleh menggunakan ragi roti yaitu sebanyak 23,08 \% dengan konsentrasi ragi roti $0,4 \%(\mathrm{~b} / \mathrm{v})$.

Ekstrak nenas dan ragi roti sama-sama menunjukkan aktivitas sebagai enzim protease yaitu dapat memecah ikatan peptida pada emulsi krim santan.. Oleh karenanya, Silaban, Mannulang, \& Hutapea (2014) mengkombinasikan teknik enzimatis dengan menggunakan enzim bromelin dengan teknik fermentasi menggunakan ragi tempe untuk memperoleh VCO, agar rendemen VCO yang dihasilkan lebih banyak dibandingkan hanya menggunakan salah satu metode saja. Dari hasil penelitiannya menunjukkan bahwa rendemen VCO yang dihasilkan yaitu 30,45 mL / $100 \mathrm{~mL}$ krim santan. Enzim protease yang ditambahkan kedalam krim santan akan memutuskan ikatan peptida dan menyebabkan minyak keluar dari gumpalan protein sehingga jumlah VCO yang dihasilkan semakin meningkat dengan meningkatnya penambahan konsentrasi ekstrak nanas. Ragi tempe dalam penelitian ini bertujuan untuk merusak 
dinding sel protein agar globula minyak dapat terpisah sedangkan ekstrak nanas digunakan untuk menghidrolisis ikatan peptida pada emulsisantan.

Kue Bay Tat, merupakan makanan khas dari provinsi Bengkulu. Sebagai makanan khas daerah, maka di Bengkulu banyak sekali industri rumah tangga yang memproduksi makanan ini. Hampir setiap wisatawan yang berkunjung ke Bengkulu pasti tidak lupa untuk membawa makanan ini sebagai buah tangan. Makanan ini terbuat dari tepung terigu dan santan kelapa yang diberi toping selai nanas.. Pembuatan toping selai nanas hanya memanfaatkan daging buah dan bonggol nanas, sedangkan bagian buah nanas yang lain akan dibuang, sehingga akan diperoleh limbah nanas yaitu berupa kulit, bagian mata, batang dan mahkota. Limbah ini sangat disayangkan jika tidak dimanfaatkan. Oleh karenanya, pada penelitian ini akan digunakan kulit dan mata nanas sebagai sumber enzim bromelin.

Palilingan \& Pungus (2018) telah melakukan penelitian mengenai pembuatan VCO dengan metode enzimatis dan dilanjutkan dengan pemurnian menggunakan adsorben zeolit alam. Hasil penelitian menunjukkan bahwa VCO yang dihasilkan dapat menurunkan kandungan air dan asam lemak bebas . Hal yang sama juga telah dilakukan oleh Handayani \& Enjarlis (2016), VCO yang dihasikan kemudian dimurnikan dengan zeolit alam 3A terbukti mampu menurunkan kadar air, bilangan asam dan bilangan peroksida. Selain menggunakan zeolit alam, VCO juga dapat dimurnikan dengan adsorben arang aktif dan abu sekam padi (Fatimah \& Sangi, 2010). Hasil dari proses pemurnian VCO, tidak hanya dapat menurunkan nilai kadar air dan asam lemak bebasnya, namun juga dapat menjernihkan VCO yang dihasilkan(Fajrin, 2012).

Pada penelitian ini, akan dilakukan pembuatan VCO dengan metode kombinasi enzimatis dan fermentasi menggunakan ekstrak nanas dan ragi roti yang sama-sama mengandung enzim protease sebagai biokatalisator, dengan harapan dapat meningkatkan rendemen VCO jika dibandingkan hanya menggunakan satu sumber enzim protease. Selain itu juga, VCO yang diperoleh kemudian akan dilakukan pemurnian dengan memanfaatkan adsorben zeolit alam yang berasal dari propinsi Bengkulu dan abu sekam padi, agar dihasilkan kualitas VCO yang lebih baik dan sesuai dengan SNI 01-2901-2008.

\section{METODE PENELITIAN Alat dan Bahan}

Alat yang digunakan ini antara lain alat-alat gelas laboratorium (Pyrex), neraca analitik (Symmetry), buret, statif dan klem, penangas air, kertas saring, pisau, talenan, blender (Philips), stoples plastik transparan, mesin parutan kelapa, saringan kelapa, oven (Thermo Scientific), desikator, oven furnace (Noberthem), lumpang dan alu, $\mathrm{pH}$ meter (Hanna).

Bahan yang akan digunakan dalam penelitian adalah krim santan dari varietas kelapa hibrida, daging dan mata nanas, ragi roti (fermipan), kloroform (Asia Lab), natrium tiosulfat (Merck), indikator fenolftalein (Merck), alkohol 96\% (Merck), kalium hidroksida (Merck), asam asetat (Merck), natrium hidroksida (Merck), dan kalium iodida (Merck), Pb-asetat (Merck), amilum, zeolit alam dan abu sekam padi. 


\section{Prosedur Kerja}

\section{Persiapan Sampel \\ a. Ekstrak Nanas}

Sampel yang berupa daging dan mata nanas diperoleh dari usaha kue Tat Citra Sari di kelurahan sukarami Bengkulu. Sampel kemudian dibersihkan dengan menggunakan air untuk menghilangkan kotoran yang masih menempel, dipotong kecil-kecil dan diblender Setelah itu disaring, filtrat hasil penyaringan kemudian digunakan untuk membuat VCO.

\section{b. Zeolit Alam}

Zeolit alam yang digunakan berasal dari Desa Karangtinggi. Zeolit alam kemudian dibersihkan dan dicuci dengan air. Setelah itu dikeringkan dan ditumbuk hingga menjadi serbuk. Serbuk zeolit alam kemudian dikalsinasi pada suhu $400-500{ }^{\circ} \mathrm{C}$ selama 2 jam.

\section{c. Abu Sekam Padi}

Sekam padi dicuci, kemudian dikeringanginkan, lalu diabukan dalam tanur pada temperatur $500{ }^{\circ} \mathrm{C}$ selama 1 jam sampai menjadi abu. Abu kemudian didinginkan dalam desikator dan disimpan dalam wadah.

\section{Uji Identifikasi Enzim Bromelin Kasar}

Uji identifikasi enzim bromelin kasar dilakukan melalui uji belerang ( $\mathrm{PbS})$. Cara identifikasi dilakukan dengan menyiapkan sebanyak $2 \mathrm{~mL}$ larutan protein (ekstrak nenas), kemudian menambahkan $5 \mathrm{~mL} \mathrm{NaOH} 10 \%$ dan dipanaskan selama

5 menit. Selanjutnya menambahkan 2 tetes larutan $\mathrm{Pb}$-asetat 5\%. Pemanasan dilanjutkan sampai terjadi perubahan warna pada larutan. Hasil uji ini positif dengan terbentuknya larutan kecoklatan dan endapan hitam pada larutan. (Silaban, Mannulang, \& Hutapea, 2014)

\section{Proses pembuatan VCO \\ a. Pembuatan Santan dan Krim}

Buah kelapa yang sudah tua dikupas dan daging buahnya diparut sebanyak $8 \mathrm{Kg}$. Daging kelapa parut dipress dengan menggunakan mesin press tanpa penambahan air. Santan yang diperoleh dipindahkan kedalam wadah topless plastik transparan bertutup dan didiamkan selama \pm 1 jam sampai terbentuk 2 lapisan, lapisan atas berupa krim (kental) dan lapisan bawah berupa skim (cair). Pada pembuatan Virgin Coconut Oil yang digunakan lapisan atas yaitu krim (Silaban, Mannulang, \& Hutapea, 2014).

\section{b. Penambahan Ekstrak Nanas dan Ragi Roti}

Sebanyak $100 \mathrm{~mL}$ krim santan dimasukkan ke dalam toples kemudian ditambahkan $10 \mathrm{~mL}$ ekstrak nanas dan $1 \mathrm{~g}$ ragi roti. Setiap campuran diatur $\mathrm{pH}$ nya menjadi 4 dengan cara mencampurkan asam asetat $6 \mathrm{M}$. Campuran difermentasi pada tempat gelap dan tertutup, pada suhu kamar selama 6; 12; 18 dan 24 jam, sehingga akan terbentuk 3 lapisan. Minyak kelapa murni yang terbentuk dipisahkan dengan cara minyak yang berada di lapisan atas diambil dengan sendok dan kemudian disaring menggunakan corong kaca yang telah dilapisi dengan kapas dan tisu makan. Disiapkan larutan kontrol, yaitu tanpa penambahan ekstrak nenas dan ragi roti.Setiap perlakuan dilakukan secara duplo. VCO yang diperoleh kemudian ditimbang dan dihitung rendemennya dengan rumus : 


$$
\text { Rendemen }(\%)=\frac{\text { Volume minyak VCO }}{\text { Volume krim santan }} \times 100 \%
$$

(Maradesa, Fatimah, \& Sangi, 2014)

\section{Pemurnian VCO dengan Zeolit Alam dan Abu Sekam Padi}

VCO yang telah diperoleh kemudian dimurnikan dengan menggunakan zeolit alam dan abu sekam padi. Ditimbang adsoben zeolit alam sebanyak $150 \mathrm{~g}$ sedangkan abu sekam padi 32 g. Pemurnian VCO dilakukan dengan menggunakan pipa paralon dengan ukuran panjang $45 \mathrm{~cm}$ dan diameter $3 \mathrm{~cm}$ dengan tinggi adsorben $30 \mathrm{~cm}$. Bagian bawah pipa diberi kapas dan tisu makan serta kertas saring. Sampel VCO dialirkan tetes demi tetes dengan kecepatan alir 1 tetes/detik dan ditampung dalam labu Erlenmeyer, selanjutnya sampel VCO dianalisis kadar air, bilangan peroksida dan asam lemak bebasnya (Fatimah \& Sangi, 2010)

\section{Karakterisasi VCO}

\section{a. Penentuan Kadar Air}

Sebanyak 5 gram minyak dimasukkan kedalam cawan porselen yang telah diketahui beratnya. Kemudian dikeringkan dalam oven pada suhu $105^{\circ} \mathrm{C}$ selama 3-5 jam dan didinginkan dalam desikator. Lalu ditimbang dengan neraca analitik sampai diperoleh berat konstan. Kadar air dapat dihitung dengan rumus:

$$
\text { Kadar air }(\%)=\frac{a-b}{c} \times 100 \%
$$

Keterangan :

$\mathrm{a}=$ Berat Cawan Porselen + Berat Sampel awal $(\mathrm{g})$

$\mathrm{b}=$ Berat Cawan Porselen + Berat Sampel Sesudah Dikeringkan (g)

$\mathrm{c}=$ berat sampel awal $(\mathrm{g} / \mathrm{sampel})$

(Rindawati, Perasulmi, \& Kurniawan, 2020)

\section{b. Penentuan Kadar Asam Lemak Bebas}

Sebanyak 2 gram sampel dimasukkan ke dalam labu erlenmeyer, kemudian ditambahkan $50 \mathrm{~mL}$ alkohol $96 \%$ selanjutnya ditambahkan 3 tetes indikator phenophtalein dan titrasi dengan larutan $\mathrm{NaOH} 0,1 \mathrm{~N}$ hingga warna merah muda. Didiamkan selama 15 detik. Kadar asam lemak bebas dapat dihitungdengan rumus:

$$
\text { Asam Lemak Bebas }(\%)=\frac{V \times \mathbb{N} \times 200}{m \times 1000} \times 100 \%
$$

Keterangan :

$\mathrm{V}=$ Volume $\mathrm{NaOH}$ yang diperlukan dalam titrasi $(\mathrm{mL})$

$\mathrm{N}=$ Normalitas $\mathrm{NaOH}$

$\mathrm{m}=$ Bobot sampel (gram)

$200=$ Bobot molekul asam laurat 
(Rindawati, Perasulmi, \& Kurniawan, 2020)

\section{c. Penentuan Bilangan Peroksida}

Sebanyak 2 gram minyak dimasukkan dalam erlenmeyer, kemudian ditambahkan $12 \mathrm{~mL}$ kloroform dan $18 \mathrm{~mL}$ asam asetat glasial Setelah minyak larut ditambahkan $1 \mathrm{~mL}$ larutan kalium iodida jenuh dan didiamkan selama 30 menit di raunag gelap. Kemudian ditambahkan $30 \mathrm{~mL}$ akuades. Kemudian dititrasi dengan natrium tiosulfat $0,1 \mathrm{~N}$ sampai warna kuning hampir hilang (kuning pucat). Kemudian ditambahkan dengan indikator amilum $1 \%$ sebanyak $0,5 \mathrm{~mL}$. Campuran di titrasi kembali sampai warna biru hilang. Dengan cara yang sama dibuat juga penentuan blanko. Jumlah natrium tiosulfat untuk titrasi sampel dan blanko dicatat. Bilangan peroksida dapat dihitung dengan rumus:

$$
\text { Bilangan Peroksida (Meq Peroksida/ Kg minyak) }=\frac{(a-b) \times \mathbb{N} \times 1000}{G} \times 100 \%
$$

Keterangan:

$\mathrm{N}=$ Normalitas larutan Natrium tiosulfat

$\mathrm{G}=$ Berat minyak (gram)

$\mathrm{a}=$ jumlah $\mathrm{mL}$ Natrium tiosulfat untuk titrasi sampel

$\mathrm{b}=$ jumlah $\mathrm{mL}$ Natrium tiosulfat untuk titrasi blanko

(Nodjeng, Fatimah, \& Rorong, 2013)

\section{HASIL PENELITIAN DAN PEMBAHASAN}

Hasil Uji Identifikasi Enzim Bromelin

Berdasarkan hasil pengamatan dapat diketahui bahwa ekstrak nanas positif mengandung belerang, dengan terbentuknya endapan hitam $\mathrm{PbS}$. Ketika larutan ekstrak nenas ditambahkan dengan $\mathrm{NaOH}$ dan kemudian dipanaskan, larutan menjadi keruh. Hal ini disebabkan penambahan $\mathrm{NaOH}$ menyebabkan belerang yang terdapat pada asam amino sistein terurai menjadi ion sulfida. Selanjutnya, dengan penambahan $\mathrm{Pb}$-Asetat, ion sulfida yang terlepas dari sistein akan bereaksi dengan ion $\mathrm{Pb}^{2+}$ dari $\mathrm{Pb}$-Asetat membentuk endapan hitam, PbS (Silaban, Mannulang, \& Hutapea, 2014)

\section{Hasil Uji Kualitatif dan Kuantitatif VCO sebelum pemurnian}

Tabel 1 berikut ini menunjukkan hasil analisa kuantitatif dan kualitatif VCO sebelum dilakukan pemurnian dengan menggunakan adsorben zeolit alam Bengkulu 
Tabel 1. Hasil Kuantitatif dan Kualitatif VCO Sebelum Pemurnian

\begin{tabular}{|c|c|c|c|c|c|c|}
\hline $\begin{array}{c}\text { Waktu } \\
\text { Fermentasi } \\
\quad \text { (jam) }\end{array}$ & $\operatorname{Rendemen}(\%)$ & $\begin{array}{c}\text { Kadar Air } \\
(\%)\end{array}$ & $\begin{array}{r}\text { Asam } \\
\text { Lemak } \\
\text { Bebas } \\
(\%) \\
\end{array}$ & $\begin{array}{c}\text { Bil. } \\
\text { Peroksida } \\
(\mathbf{m e q} / \mathbf{K g})\end{array}$ & Warna & Aroma \\
\hline 6 & 20,15 & 0,4 & 0,296 & 0,985 & kuning & $\begin{array}{l}\text { Minyak } \\
\text { kelapa }\end{array}$ \\
\hline 12 & 25,06 & 0,6 & 0,396 & 2,704 & kuning & $\begin{array}{l}\text { Minyak } \\
\text { kelapa }\end{array}$ \\
\hline 18 & 32,96 & 0,79 & 0,488 & 3,675 & kuning & $\begin{array}{l}\text { Minyak } \\
\text { kelapa }\end{array}$ \\
\hline 24 & 43,24 & 0,79 & 0,633 & 2,225 & kuning & $\begin{array}{l}\text { Minyak } \\
\text { kelapa }\end{array}$ \\
\hline
\end{tabular}

Pada Tabel 1 terlihat bahwa hasil rendemen VCO terbesar diperoleh pada waktu inkubasi selama 24 jam yaitu sebesar 43,24\%. Semakin lama waktu fermentasi, maka proses pemecahan emulsi santan akan terus berjalan, sehingga kecepatan reaksi hidrolisis protein semakin meningkat sehingga minyak yang dapat dibebaskan dari selubung protein juga semakin banyak sehingga rendemen semakin besar. Peningkatan rendemen minyak yang terjadi juga disebabkan karena pada awal fermentasi sel-sel enzim bromelin berada dalam keadaan pertumbuhan sehingga mencapai jumlah yang maksimum (Ishak, Aji, \& Israwati, 2015). Pemecahan protein yang dipengaruhi oleh adanya enzim protease yang terdapat pada enzim bromelin dari ekstrak kasar nanas dan juga ragi roti yaitu mikroorganisme Saccharomyces sereviceae menyebabkan sistem emulsi pada santan menjadi tidak stabil sehingga minyak dapat terpisah dari sistem emulsi.

Pada penelitian ini juga dilakukan perhitungan rendemen untuk kontrol yaitu tanpa penambahan ekstrak nanas dan ragi roti serta penambahan ragi roti saja ataupun ekstrak nanas saja. Hasil rendemen yang diperoleh dapat dilihat pada Gambar 1 berikut ini

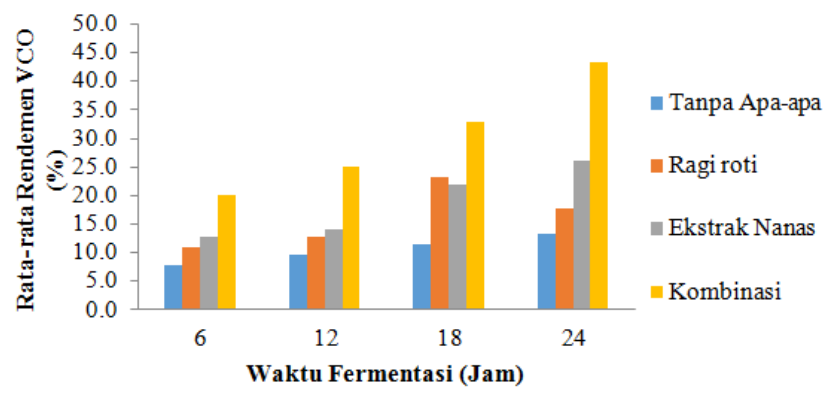

\section{Gambar 2. Grafik rata-rata rendemen VCO pada berbagai variasi waktu dan perlakuan}

Pada Gambar 1 diatas, terlihat bahwa rendemen VCO yang dihasilkan jika tanpa menggunakan ekstrak nanas dan ragi roti menunjukkan hasil yang lebih kecil dibandingkan dengan menggunakan ragi roti saja, ekstrak nanas saja ataupun 
kombinasi ekstrak nanas dan ragi roti pada semua variasi waktu fermentasi. Dari data tersebut dapat menunjukkan adanya peran ekstrak nanas dan ragi roti dalam meningkatkan rendemen VCO. Enzim protease yang terdapat pada ekstrak nanasdan ragi roti mampu berperan sebagai biokatalisator dalam mempercepat terjadinya hidrolisis ikatan peptida yang terdapat pada emulsi santan sehingga ikatan peptida terputus dan protein rusak sehingga minyak dapat keluar dari sistem emulsi santan. Pada penelitian ini, sebelum dilakukannya pemurnian, warna VCO yang dihasilkanberwarna kuning. Hasil ini tidak sesuai dengan SNI 2008 dimana VCO harus berwarna jernih sedangkan menurut APCC warna VCO yaitu kuning pucat sampai jernih. Hal ini dikarenakan adanya pengaruh dari penambahan ekstrak nanas yang ditambahkan sebagai biokatalisator dalam pembuatan VCO.

Berdasarkan karakterisasi hasil VCO yang diperoleh yang meliputi kadar air, asam lemak bebas dan bilangan peroksida terlihat bahwa untuk parameter kadar air, maka nilai nya tidak memenuhi SNI yaitu minimal 0,5. Tingginya kadar air pada VCO yang dihasilkan dapat dipengaruhi oleh kadar air yang terdapat pada ekstrak nanas. Kandungan air pada bahan dapat menentukan penerimaan konsumen, kesegaran dan daya tahan bahan. Kandungan air yang tinggi mengakibatkan daya tahan bahan rendah. Tingginya kandungan air ini juga mengakibatkan reaksi hidrolisis yang dapat menyebabkan minyak menjadi tengik (Winarno, 1997). Selain itu juga dapat dikarenakan bercampurnya air pada saat pembuatan dan tidak bisa dipisahkan dengan metode pemisahan biasa (Simangunsong, Febrina, \& Masyitah, 2016). Sama halnya untuk parameter kadar asam lemak, maka nilai yang dihasilkan belum memenuhi SNI 2008 yaitu maksimum sebesar 0,2\% sedangkan menurut APCC sebesar 0,5\%. Pada Tabel 1 terlihat bahwa dengan semakin lamanya waktu fermentasi, maka kadar asam lemak semakin meningkat, hal ini sejalan dengan kadar air yang juga semakin meningkat dengan lamanya waktu fermentasi. Nilai kadar asam lemak dipengaruhi oleh jumlah air yang terkandung pada VCO. jika kadar air tinggi, maka dapat terjadi proses hidrolisis yang akan melepaskan asam

lemak rantai pendek yang dapat menyebabkan timbulnya bau. Dengan adanya air, lemak akan terhidrolisis membentuk gliserol dan asam lemak bebas (Ngatemin, Nurrahman, \& Isworo, 2013).

Sedangkan untuk parameter bilangan peroksida, telah memenuhi SNI 2008. Dimana menurut SNI 2008, nilai maksimum bilangan peroksida sebesar 5 meq $/ \mathrm{kg}$. Namun, jika berdasarkan standar APCC, nilai bilangan peroksida ini berada diatas nilai maksimum yaitu $3 \mathrm{meq} / \mathrm{Kg}$. Menurut Augustyn (2012) penyebab terjadinya kenaikan angka peroksida yaitu banyaknya air yang terkandung dalam santan dan molekulmolekul minyak atau yang mengandung radikal asam lemak tidak jenuh sehingga mengalami oksidasi dan menjadi tengik. Sejumlah air yang terkandung dalam lemak dapat menjadi medium yang baik bagi pertumbuhan jamur yang dapat menghasilkan enzim peroksida (Ketaren, 1986)

VCO yang telah diperoleh kemudian dimurnikan dengan menggunakan adsorben zeolit alam bengkulu dan abu sekam padi. Dimana diketahui bahwa berdasarkan penelitian Nurani, Septyaningsih, Hardiyanti, \& Wibowo (2016) adsorben zeolit alam telah terbukti mampu untuk memurnikan minyak bahkan pada minyak jelantah. 


\section{Hasil Uji Kuantitatif dan Kualitatif VCO Setelah Pemurnian dengan Zeolit Alam Bengkulu dan Abu Sekam Padi}

Pemurnian VCO bertujuan untuk mendapatkan kualitas VCO yang lebih baik. Fatimah \& Sangi (2010) telah melakukan penelitian tentang pemurnian VCO menggunakan zeolit alam, abu sekam padi dan arang aktif. Hasil penelitian menunjukkan bahwa VCO yang dihasilkan setelah pemurnian, dapat menurunkan nilai kadar air, bilangan peroksida dan bilangan asam. Tabel 2 berikut ini menunjukkan hasil uji kuantitatif dan kualitatif VCO setelah proses pemurniandengan menggunakan zeolit alam bengkulu dan abu sekam padi

Tabel 2. Hasil Uji Kuantitatif dan Kualitatif VCO setelah pemurnian

\begin{tabular}{|c|c|c|c|c|c|c|}
\hline Adsorben & $\begin{array}{c}\text { Waktu } \\
\text { (jam) }\end{array}$ & $\begin{array}{c}\text { Kadar } \\
\text { Air } \\
(\%)\end{array}$ & $\begin{array}{c}\text { Asam } \\
\text { Lemak } \\
\text { Bebas }(\%)\end{array}$ & $\begin{array}{c}\text { Bil. } \\
\text { Peroksida } \\
(\mathrm{meq} / \mathrm{Kg})\end{array}$ & Warna & Aroma \\
\hline \multirow{4}{*}{$\begin{array}{l}\text { Zeolit } \\
\text { alam }\end{array}$} & 6 & 0,2 & 0,098 & 0,985 & Bening & $\begin{array}{c}\text { Minyak } \\
\text { kelapa }\end{array}$ \\
\hline & 12 & 0,19 & 0,148 & 1,74 & Bening & $\begin{array}{c}\text { Minyak } \\
\text { kelapa }\end{array}$ \\
\hline & 18 & 0,2 & 0,292 & 1,73 & Bening & $\begin{array}{c}\text { Minyak } \\
\text { kelapa }\end{array}$ \\
\hline & 24 & 0,4 & 0,197 & 0,495 & Bening & $\begin{array}{c}\text { Minyak } \\
\text { kelapa }\end{array}$ \\
\hline \multirow{4}{*}{$\begin{array}{c}\text { Abu } \\
\text { Sekam } \\
\text { Padi }\end{array}$} & 6 & 0,4 & 0,09 & 1,23 & $\begin{array}{c}\text { Kuning } \\
\text { pucat }\end{array}$ & $\begin{array}{c}\text { Minyak } \\
\text { kelapa }\end{array}$ \\
\hline & 12 & 0,4 & 0,197 & 1,49 & $\begin{array}{c}\text { Kuning } \\
\text { pucat }\end{array}$ & $\begin{array}{c}\text { Minyak } \\
\text { kelapa }\end{array}$ \\
\hline & 18 & 0,4 & 0,245 & 2,2 & $\begin{array}{c}\text { Kuning } \\
\text { pucat }\end{array}$ & $\begin{array}{c}\text { Minyak } \\
\text { kelapa }\end{array}$ \\
\hline & 24 & 0,4 & 0,294 & 1,23 & $\begin{array}{c}\text { Kuning } \\
\text { pucat }\end{array}$ & $\begin{array}{c}\text { Minyak } \\
\text { kelapa }\end{array}$ \\
\hline
\end{tabular}

Berdasarkan Tabel 2 dapat dilihat bahwa nilai kadar air, asam lemak bebas dan bilangan peroksida VCO setelah dilakukan pemurnian dengan adsorben zeolit alam dan abu sekam padi menunjukkan nilai yang lebih rendah dibandingkan sebelum dilakukan pemurnian. Dengan adanya perlakuan pemurnian VCO dengan dilewatkan menggunakan asdorben zeolit dan abu sekam padi terbukti dapat menurunkan kadar air dan asam lemak bebas serta bilangan peroksida VCO secara signifikan. Adanya pemurnian VCO dengan menggunakan adsorben zeolit dan abu sekam padi terbukti berhasil menjerap sejumlah air dan asam lemak bebas, sehinggakadar air dalam produk VCO berkurang demikian juga dengan nilai kadar asam lemak sehingga kualitas VCO menjadi lebih baik.

Lipid peroksida yang ada pada minyak bersifat lebih polar dibanding minyak yang belum terkontaminasi dengan senyawa pemicu peroksida, oleh sebab itu lipid peroksida tersebut bisa terjerap dalam adsorben, sehingga setelah disaring menggunakan 
adsorben bilangan peroksida dari VCO tersebut bisa berkurang.

Perbandingan warna VCO yang dihasilkan sebelum dan setelah pemurnian dengan zeolit dan abu sekam padi menunjukkan bahwa warna VCO mengalami pemucatan. Dengan dialirkan melalui zeolit maka awalnya VCO yang berwarna kuning menjadi jernih/bening. Sedangkan jika dilalui dengan adsorben abu sekam padi, warna VCO yang semula kuning menjadi kuning pucat namun tidak sampai menjadi bening. Dengan demikian, zeolit alam mempunyai kemampuan menjerap warna VCO lebih baik dibandingkan abu sekam padi.

Jika dilihat dari parameter aroma, pemurnian dengan menggunakan zeolit alam dan abu sekam padi tidak mempengaruhi aroma VCO yang dihasilkan. Aroma tidak berubah, sehingga masih beraroma khas minyak kelapa.

\section{SIMPULAN}

Dari penelitian ini dapat diperoleh kesimpulan bahwa Ekstrak nanas dan ragi roti dapat digunakan sebagai biokatalisator dalam proses pembuatan Virgin Coconut Oil (VCO), diperoleh rendemen VCO yang lebih tinggi menggunakan kombinasi ekstrak nanas dan ragi roti jika dibandingkan tanpa kombinasi. Sedangkan berdasrkan lama fermentasi, maka semakin lama waktu fermentasi akan dihasilkan rendemen yang semakin besar. Rendemen VCO terbesar diperoleh pada waktu 24 jam yaitu 43,24 \%.

Pemurnian VCO dengan menggunakan zeolit alam bengkulu dan abu sekam padi terbukti dapat menurunkan nilai kadar air, asam lemak bebas dan bilangan peroksida, serta mampu membuat warna VCO menjadi lebih pucat (dari kuning menjadi kuning pucat dan bening) sedangkan untuk parameter aroma tidak berpengaruh (tetap beraroma khas minyak kelapa). Hasil karakterisasi kadar air, asam lemak bebas dan bilangan peroksida setelah pemurnian telah memenuhi standar SNI 2008.

Penelitian selanjutnya sebaiknya menggunakan variasi waktu fermentasi lebih dari 24 jam sehingga dapat diperoleh rendemen maksimum dari VCO, selain itu juga perlu adanya perlakuan sentrifugasi agar proses pemecahan emulsi santan lebih cepat.

\section{UCAPAN TERIMAKASIH}

Penulis mengucapkan terimakasih kepada Fakultas MIPA Universitas Bengkulu yang telah membiayai penelitian ini melalui RBA FMIPA tahun 2020, nomor kontrak 2048/UN30.12/HK/2020 dengan skim Penelitian Pembinaan FMIPA. Terimakasih juga kepada mahasiswa atas nama Sitti Khoirani Oktavia dan Nea Lestari Agustin Sive yang telah membantu penelitian ini.

\section{DAFTAR RUJUKAN}

Aditya, R., Rusmarilin, H., \& Limbong, L. N. (2014). Optimasi Pembuatan Virgin Coconut Oil (VCO) Dengan Penambahan Ragi Roti (Saccharomyces cerevisiae) Dan Lama Fermentasi Dengan VCO Pancingan. Jurnal Rekayasa Pangan dan Pertanian, 2 (2), 51-57.

Augustyn, G. H. (2012). Pengaruh Penambahan Ekstrak Buah Pepaya (Carica papaya L.) Terhadap Mutu Minyak Kelapa Murni. Jurnal Budidaya Pertanian , 8 (1), 55-60.

Diyah, N. W., Purwanto, Susanti, Y., \& Dewi, Y. K. (2010). Pembuatan Minyak Kelapa 
Secara Enzimatis Dengan Memanfaatkan Kulit Buah Dan Biji Pepaya Serta Analisis Sifat Fisikokimianya. Berk. Penel. Hayati , 15, 181- 185.

Fajrin, E. (2012). Penggunaan Enzim Bromelin pada Minyak Kelapa Murni (Cocus nucifera) Secara Enzimatis. Universitas Hasanudin. Makassar: Universitas Hasanudin.

Fatimah, F., \& Sangi, M. E. (2010). Kualitas Pemurnian Virgin Coconut Oil (VCO) Menggunakan Beberapa Adsorben. Chem.Prog , 3 (2), 65-69.

Fuad, M. (2012). Analisis Jenis Dan Konsentrasi Enzim Terhadap Daya Simpan VCO (Virgin Coconut Oil). Agrointek , 6 (2), 112-117.

Handayani, S., \& Enjarlis. (2016). Pemurnian Virgin Coconut Oil Menggunakan Zeolit 3A Sebagai Bahan Baku Obat Kulit. JBAT, 5 (2), 61-67.

Ishak, Aji, A., \& Israwati. (2015). Pengaruh Waktu Fermentasi Dan Berat Bonggol Nanas Pada Pembuatan Virgin Coconut Oil (VCO) . Jurnal Teknologi Kimia Unimal , 66-77.

Ketaren, S. (1986). Pengantar Teknologi Minyak dan Lemak Pangan. Jakarta: UIPress.

Mansor, S., Che Man, Y., Suhaimi, M., Abdul Afiq, M., \& Ku Nurul, F. (2013). Physicochemical Properties of Virgin Coconut Oil Extracted from Different Processing Methods. International Food Research Journal, 19 (3), 837-845.

Maradesa, R. P., Fatimah, F., \& Sangi, M. S. (2014). Kualitas Virgin Coconut Oil (VCO) Sebagai Minyak Goreng yang Dibuat dengan Metode Pengadukan dengan Adanya Penambahan Kemangi (Ocimum sanctum L.). Jurnal MIPA UNSTRAT , 3 (1), 44-48.

Mujdalipah, S. (2016). Pengaruh Ragi Tradisional Indonesia Dalam Proses Fermentasi Santan Terhadap Karakteristik Rendemen, Kadar Air, Dan Kadar Asam Lemak Bebas Virgin Coconut Oil (VCO). Fortech , 1 (1), 10-15.

Ngatemin, Nurrahman, \& Isworo, J. T. (2013). Pengaruh Lama Fermentasi Pada Produksi Minyak Kelapa Murni (Virgin Coconut Oil) Terhadap Sifat Fisik, Kimia,Dan Organoleptik. Jurnal Pangan dan Gizi , 4 (8), 9-18.

Ngatemin, Nurrahman, \& Isworo, J. T. (2013). Pengaruh Lama Fermentasi Pada Produksi Minyak Kelapa Murni (Virgin Coconut Oil) Terhadap Sifat Fisik, Kimia,Dan Organoleptik. Jurnal Pangan dan Gizi , 4 (8), 9-18.

Nodjeng, M., Fatimah, F., \& Rorong, J. A. (2013). Kualitas Virgin Coconut Oil (Vco) Yang Dibuat Pada Metode Pemanasan Bertahap Sebagai Minyak Goreng Dengan Penambahan Wortel (Daucus carrota L.). Jurnal Ilmiah Sains , 13 (2), 102-109.

Nurani, I., Septyaningsih, D., Hardiyanti, I. S., \& Wibowo, E. A. (2016). Analisis Keefektivan Zeolit pada Proses Adsorbsi Pemurnian Minyak Jelantah. Seminar Nasional XI "Rekayasa Teknologi Industri dan Informasi 2016" (pp.368-372). Yogyakarta: Sekolah Tinggi Teknologi Nasional.

Palilingan, S., \& Pungus, M. (2018). Produksi enzimatis Virgin Coconut Oil (VCO) dengan enzim bromelin serta pemurniannya menggunakan adsorben zeolit. Fullerene Journ. Of Chem , 3 (2), 70-74.

Rindawati, Perasulmi, \& Kurniawan, E. W. (2020). Studi Perbandingan Pembuatan 
Dalton : Jurnal Pendidikan Kimia dan Ilmu Kimia, Volume 4 Nomor 1, Mei 2021

VCO (Virgin Coconut Oil) Sistem Enzimatis dan Pancingan Terhadap Karakteristik Minyak Kelapa Murni yang Dihasilkan. Indonesian Journal of Laboratory, 2 (2), 25-32.

Silaban, R., Mannulang, R. S., \& Hutapea, V. (2014). Pembuatan Virgin Coconut Oil (VCO) Melalui Kombinasi Teknik Fermentasi Dan Enzimatis Menggunakan Ekstrak Nenas. Jurnal Pendidikan Kimia , 6 (1), 91-99.

Simangunsong, J., Febrina, E., \& Masyitah, Z. (2016). Pengaruh Penambahan Inokulum, Lama Fermentasi dan Pengadukan Pada Pembuatan Virgin Coconut Oil (VCO) Menggunakan Khamir Saccharomyces Cerevisiae Murni. Jurnal Teknik Kimia USU , 5 (3), 24-30.

Winarno, F. G. (1997). Kimia Pangan dan Gizi. Jakarta: PT.Gramedia 